\title{
Localization and characterization of somatostatin binding sites in the mouse retina
}

\author{
Malgorzata Kossut ${ }^{1, *}$, Tadataka Yamada ${ }^{2}$, Leslie B. Aldrich ${ }^{2}$ and Lawrence H. Pinto ${ }^{1}$

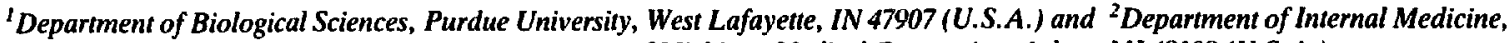 \\ Gastroenterology Division, University of Michigan Medical Center, Ann Arbor, MI 48109 (U.S.A.)
}

(Accepted 21 June 1988)

Key words: Somatostatin; Retina; Receptor; Mouse

\begin{abstract}
We studied the binding of $\left[{ }^{125} \mathrm{I}\right] \mathrm{Tyr}^{1{ }^{1}}$-somatostatin-14 and $\left[{ }^{125} \mathrm{I}\right] \mathrm{Leu}^{8}, \mathrm{D}-\mathrm{Tr}^{22}$,Tyr ${ }^{25}$-somatostatin-28 to frozen, unfixed sections of C57BL/6J mouse eyes with autoradiography. Specific binding of both ligands occurred in 3 maxima, a broad band extending from the retinal ganglion cell to the inner nuclear layers, a narrow and inconstant band over the outer plexiform layer, and a band over the retinal pigment epithelium and choroid. We quantified the label over the inner plexiform layer and found evidence for a single, saturable binding site after Scatchard analysis of saturation binding data. With [ ${ }^{125} I$ ] Tyr ${ }^{11}$-somatostatin-14 the dissociation constant $\left(K_{\mathrm{d}}\right)$ was $1.48 \mathrm{nM}$ and the total number of binding sites $\left(B_{\mathrm{max}}\right)$ was $68 \mathrm{fmol} / \mathrm{mg}$ protein; in competition experiments the inhibitory binding constant $\left(K_{\mathrm{i}}\right)$ was $900 \mathrm{pM}$ for somatostatin-14 and $350 \mathrm{pM}$ for somatostatin-28. With [ $\left.{ }^{125} \mathrm{I}\right] \mathrm{Leu}{ }^{8}, \mathrm{D}-\mathrm{Trp}^{22}, \mathrm{Tyr}^{25}$-somatostatin-28, $K_{\mathrm{d}}$ was 625 $\mathrm{pM}$ and $B_{\max }$ was $69 \mathrm{fmol} / \mathrm{mg}$ protein: in competition experiments $K_{\mathrm{i}}$ was $4.58 \mathrm{nM}$ for somatostatin-14 and $710 \mathrm{pM}$ for somatostatin-28. These results demonstrate the existence of somatostatin receptors in the inner plexiform layer of the retina that appear to have greater specificity for somatostatin-28 than for somatostatin-14.
\end{abstract}

\section{INTRODUCTION}

Two molecular forms of somatostatin, one composed of 14 and the other composed of 28 amino acids, have been found in the retinas of various mammals ${ }^{10,11.18,19,23}$. Immunohistochernical studies on mammalian retinas have shown somatostatin to be located in the processes of amacrine cells in the inner plexiform layer and in processes of unidentified cells in the outer plexiform layer ${ }^{7,23,27}$. In the goldfish ${ }^{11}$ and the macaque ${ }^{12}$ the processes of these cells in the inner plexiform layer are presynaptic to amacrine, ganglion and bipolar cells.

Exogenous somatostatin, when applied in solutions superfusing the retina, has been shown to affect the retinal responses to light. Nanomolar concentrations increase the amplitude of the extracellularly-recorded, massed oscillatory potentials of the mudpuppy eyecup preparation ${ }^{30}$, and affect the responses of rabbit $^{36}$ and goldfish ${ }^{31}$ retinal ganglion cells in a variety of ways. The mouse retina can be studied in an isolated, superfused preparation ${ }^{1,24}$ and many mutants with defective visual fanction are available (see ref. 24 for review). Application of somatostatin-28 in low ( $\leqslant 10 \mathrm{nM}$ ) concentrations affects the responses of on-center retinal ganglion cells to small, centered light stimuli ${ }^{25}$.

We have searched for retinal receptors for somatostatin in order to understand the mechanism for somatostatin action. To do so we have employed quantitative autoradiography because this method allows quantification of the label in a given location and permits small amounts of tissue to be studied. Using this method, we have found specific membrane receptors for somatostatin in the inner and outer plexiform layers of the retina. We characterized the receptors in the inner plexiform layer, and found them to have a higher affinity for somatostatin 28 than for somato-

\footnotetext{
* Present address: Nencki Institute, Warsaw, Poland.

Correspondence: L.H. Pinto. Present address: Department of Neurobiology and Physiology, Hogan Hall, Northwestern University, Evanston, IL 60201, U.S.A.
} 
statin-14 and to have a dissociation constant within the range of concentration of exogenous somatostatin found to affect the responses of mouse retinal ganglion cells.

\section{MATERIALS AND METHODS}

Mice from the C57BL/6J strain (both sexes, 3-7 months of age) were used. They were maintained with a $12 \mathrm{~h}$ light $/ 12 \mathrm{~h}$ dark cycle, and were sacrificed by cervical dislocation (3-4 $\mathrm{h}$ after onset of light at $07.00 \mathrm{~h}$ ).

\section{Quantitative autoradiography}

The eyes were marked with a pen at the canthus, removed, placed in isopentane at $-140^{\circ} \mathrm{C}$ for rapid freezing, stored overnight at $-20^{\circ} \mathrm{C}$, and sectioned (at $10 \mu \mathrm{m}$ ) the next day. The mark on the canthus was used to orient the eye to make sections parallel to the optic axis. The sections were collected on slides and stored at $-20^{\circ} \mathrm{C}$ overnight. Cerebral cortices were also frozen in isopentane at $-140{ }^{\circ} \mathrm{C}$. We followed the incubation procedure of Maurer and Reubi ${ }^{13}$. The sections were preincubated $\left(2 \mathrm{mM} \mathrm{CaCl}_{2}, 5 \mathrm{mM}\right.$ $\mathrm{KCl}, 50 \mathrm{mM}$ Tris- $\mathrm{HCl}$, pH 7.4, $10 \mathrm{~min}, 21^{\circ} \mathrm{C}$ ), washed twice (50 mM Tris- $\mathrm{HCl}, \mathrm{pH} \mathrm{7.4,2}$ min. $21{ }^{\circ} \mathrm{C}$ ), and drained of excess solution. An incubation solution was then applied to the sections for $\mathbf{4 0} \mathrm{min}$ $\left(21^{\circ} \mathrm{C}\right)$. The incubation solution always contained 10 $\mathrm{mM} \mathrm{MgCl}, 1 \%$ bovine serum albumin, $40 \mu \mathrm{g} / \mathrm{ml}$ bacitracin, and $170 \mathrm{mM}$ Tris- $\mathrm{HCl}, \mathrm{pH} 7.4$. For saturation binding experiments the incubation solution also contained radiolabeled somatostatin, either $\left.{ }^{[25} \mathrm{I}\right] \mathrm{Tyr}^{11}$-somatostatin- 14 (Amersham) in concentrations from $30 \mathrm{pM}$ to $5 \mathrm{nM}$ or $\left[{ }^{125} \mathrm{I}\right] \mathrm{Leu}^{8}, \mathrm{D}-\operatorname{Trp}^{22}$. $\mathrm{Tyr}^{25}$-somatostatin-28 (iodinated using the chloramine-T method, see Yamada $^{33}$ in concentrations from $50 \mathrm{pM}$ to $2.5 \mathrm{nM}$ ). In competition experiments the incubation solution contained either $250 \mathrm{pM}$ [125I]Tyr ${ }^{11}$-somatostatin-14 or $20 \mathrm{pM}\left[{ }^{125} \mathrm{I}\right] \mathrm{Leu}^{8}, \mathrm{D}-$ $\mathrm{Trp}^{22}, \mathrm{Tyr}^{25}$-somatostatin-28 and one of many concentrations of unlabeled competitor (either somatostatin-14, somatostatin-28, somatostatin-28(1-14) or bombesin). To determine non-specific binding, 10 $\mu \mathrm{M}$ of the appropriate molecular form of somatostatin was added. After incubation the sections were washed $(0.25 \%$ bovine serum albumin and $170 \mathrm{mM}$ Tris- $\mathrm{HCl}, \mathrm{pH} 7.4$, twice for $5 \mathrm{~min}, 5^{\circ} \mathrm{C}$ ), dried rapid- ly by allowing dichlorodifluoromethane gas to flow over them, and placed in X-ray cassettes apposed to ${ }^{3} \mathrm{H}$-ultrofilm (LKB). The slides upon which the sections were mounted were coded before being placed in the cassettes. Calibrated, radioiodinated brain paste standards ${ }^{29}$ were placed in the cassette together with the sections for 1-5 days. The film was developed (in D-19 for $4 \mathrm{~min}, 18^{\circ} \mathrm{C}$ ). The histologicai sections and the autoradiograms were examined with a stereomicroscope and a dark-field compound microscope in order to identify labeling (or lack of labeling) caused by histological artifacts. The autoradiograms were superimposed upon the sections and viewed with the stereomicroscope in order to identify the part of the autoradiogram that had been in contact with the inner plexiform layer. in some cases we also needed to compare the section and autoradiogram with the dark-field microscope to make the identification. Density was measured with a microphotometer equipped with a current-regulated power supply and $60 \mu \mathrm{m}$ diameter measurement aperture (referred to the specimen plane) or an Eikonix scanning microphotometer with a $7 \mu \mathrm{m}$ pixel size (referred to the specimen plane).

Calibration of the concentration of label was done for each experiment in the following way. The optical density of the brain paste standards was measured and plotted against the concentration of isotope in the brain paste (dpm/mg protein). For short exposure times these plots could be fitted by a straight line 2 which was later used to calculate the concentration of label in the measured regions of the sectioned tissue.

We used emulsion autoradiography to help localize the retinal layers to which binding occurred. We used either the sandwich technique of Young and $\mathrm{Kuhar}^{34}$ or the dry loop technique of Caro ${ }^{3}$ to perform autoradiography using fine grain emulsion (see Fig. 2). The ${ }^{125}$ I-label that we used has the advantage over ${ }^{3} \mathrm{H}$-label ${ }^{6}$ of being insusceptible to quenching artifact ${ }^{8}$. The mean free path of ${ }^{125} I$ is somewhat longer than that of ${ }^{3} \mathrm{H}$, but sufficiently short for ${ }^{125} \mathrm{I}$ label to be helpful in localizing labeling to specific retinal layers. However, ${ }^{125}$ I label cannot provide information about cellular localization in the $10 \mu \mathrm{m}$ thick sections that we used.

\section{Binding to membrane fractions}

Retinas were isolated ${ }^{24,25}$ in a solution containing 
$\$ 50 \mathrm{mM} \mathrm{NaCl}$ and vortexed to remove the photoreceptor outer segments ${ }^{15}$. The retina or cerebral cortex was homogenized in glass-teflon Randotti homogenizers in ice cold $0.32 \mathrm{M}$ sucrose. The homogenate was centrifuged ( $5 \mathrm{~min}, 1000 \mathrm{~g}$ ); the supernatant was re-centrifuged ( $20 \mathrm{~min}, 20,000 \mathrm{~g}$ ) to obtain the $\mathrm{P} 2$ membrane fraction, within which the receptor-rich synaptosomal fraction is contained ${ }^{5.21}$, and the pellet was re-suspended in buffer (Tris- $\mathrm{HCl}, \mathrm{pH} 7.4$ ). Binding assays were performed upon $100 \mu \mathrm{l}$ samples containing $50 \mu \mathrm{g}$ protein as described by Reubi et al. ${ }^{16}$. Protein content was estimated by the method of Sedmak and Grossberg ${ }^{20}$. Statistical analysis of binding data was done with ANOVA (Type I, mixed design) followed by the Duncan test).

\section{RESULTS}

\section{Confirmation of the validity of the method using brain tissue}

We made crude mitochondrial fractions of the mouse cerebral cortex and retina and performed receptor binding assays in parallel on each tissue using $250 \mathrm{pM}\left[{ }^{125} \mathrm{i}\right] \mathrm{Tyr}^{\prime \prime}$-somatostatin-14. We found that specific binding was proportional to the amount of membrane protein in each sample. The specific binding to the cortical fractions with $250 \mathrm{pM}$ ligand was 27 fmol/mg protein, a value similar to that obtained for the binding of this ligand to rat cortical membranes under similar incubation conditions $(25 \mathrm{fmol} / \mathrm{mg}$ protein) ${ }^{16}$. The specific binding of this ligand to the retinal P2 fraction was 2-3 times less than the specific binding to cortical $P 2$ fractions with the same concentration of ligand. The non-specific binding was $30-50 \%$ of the total binding in both cortex and retiná.

We examined the pattern of labeling in film autoradiograms after incubation of coronal and parasagittal sections of the brain with $\left[{ }^{125} \mathrm{I}\right] \mathrm{Ty} \mathrm{r}^{11}$-somatostatin14. We found the distribution of label to be similar to that described by Tran et al. ${ }^{27}$, Maurer and Reubi ${ }^{13}$ and Leroux et al. ${ }^{9}$ in rats; the hippocampus and amygdala were generally heavily labeled; the cortex was heavily labeled, with a band of dense label over the infra-granular layers; non-specific binding was uniform over the sections. We simultaneously incubated sections of retinas and cortex with 100 or 250 $\mathrm{pM}$ of $\left[{ }^{125} \mathrm{I}\right] \mathrm{Tyr}^{11}$-somatostatin-14 and found the spre- cific binding to the retina to be $2-3$ times less than the specific binding to the infra-granular layers of the cortex. These results confirmed those obtained with crude mitochondrial fractions. We characterized the specific retinal binding with quantitative autoradiography.
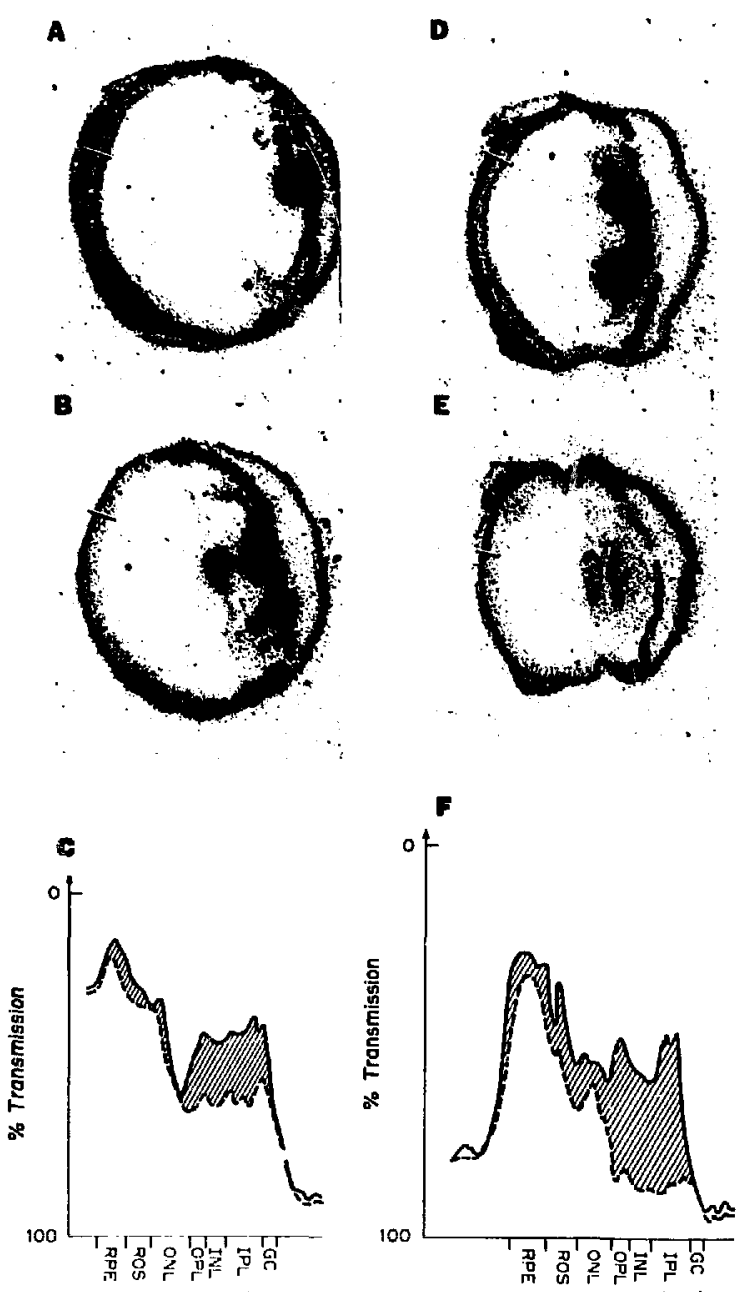

Fig. 1. Film autoradiograms (A, B, D and E) and the distribution of optical transmission ( $C$ and $F$ ) of sections of eyes that were incubated in $\left.{ }^{125} 1\right]$ Tyr $^{11}$-somatostatin-14 (A-C) and ${ }^{125}$ I]Leu ${ }^{8}, \mathrm{D}-\mathrm{Trp}^{22}$, Tyr $^{25}$-somatostatin-28 (D-F). Total binding is shown in $A$ and $D$. Non-specific binding ( $B$ and $E$ ) was obtained in the presence of $10 \mu \mathrm{M}$ unlabeled peptide (SS-14 in B and $S-28$ in E). The straight lines in the autoradiograms show the path along which optical transmission was measured. The layers of the retina that underlie the scan parh were identified from the section and are indicated in the plots in C and F. RPE, retinal pigment epithelium and choroid; ROS, rod outer segments; ONL, outer nuclear layer; OPL, outer plexiform layer; INL, inner nuclear layer; IPL, inner plexiform layer, and GC, ganglion cell layer. Note the high specific binding (hatched) in the inner plexiform layer. Scale bar $=60 \mu \mathrm{m}$. 


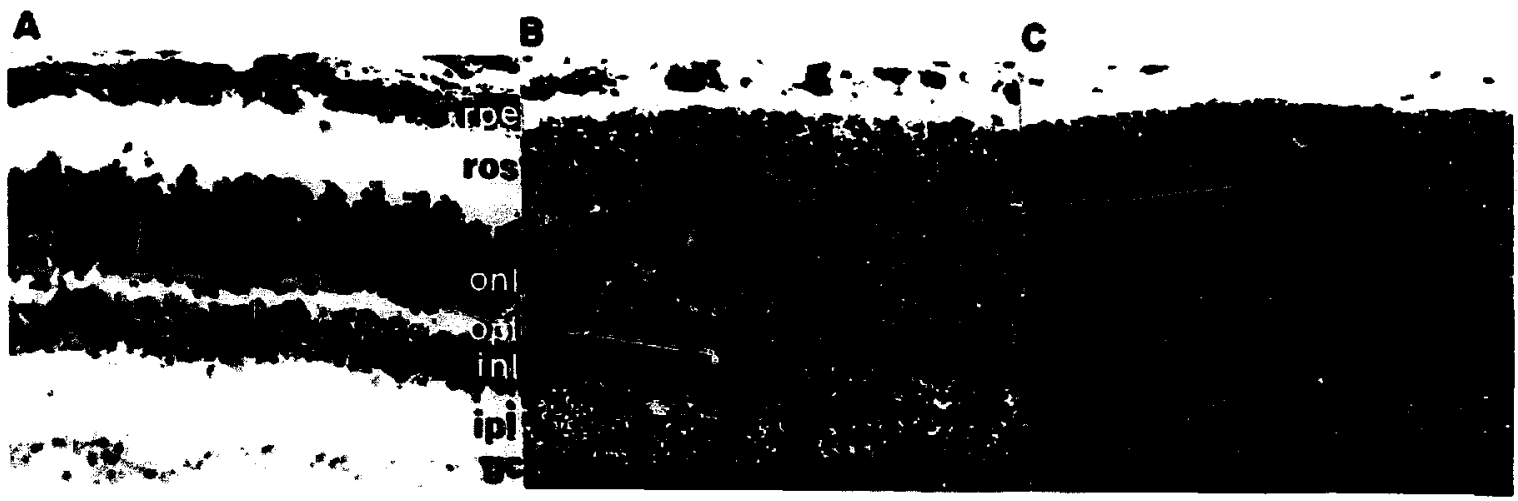

Fig. 2. Cresyl violet-stained section (A) and autoradiograms (B and C) of adjacent sections incubated with [ $\left.\left.{ }^{125} \mathrm{I}\right]\right]^{\mathrm{T} y r^{11}}$-somatostatin14. Total binding is shown in $B$ and non-specific binding, determined in the presence of $10 \mu \mathrm{M}$ unlabeled somatostatin-14. in $C$. Note the maxima of specific binding associated with the plexiform layers in (B). Abbreviations as in Fig. 1 . Scale bar $=100 \mu \mathrm{m}$.

\section{Anatomical localization of binding in the retina}

Three maxima of total binding density were found with both $\left[{ }^{125} \mathrm{I}\right] \mathrm{Tyr}^{11}{ }^{1}$-somatostatin-14 and $\left[{ }^{125} \mathrm{I}\right] \mathrm{Leu}^{8}$, $\mathrm{D}-\mathrm{Trp}^{22}, \mathrm{Tyr}^{125}$-somatostatin-28. Two of these maxima occurred in the retina and one in the retinal pigment epithelium (RPE)-choroid complex. These maxima did not appear to have different intensities in the central and peripheral parts of the eye (Fig. 1). Emulsion autoradiography (see Materials and Methods, and Fig. 2) helped to identify the labeled retinal layers. The densest labeling occurred in a broad band over the inner plexiform layer and inner margin of the inner nuclear layer. A second thin and less constant band was found over the outer plexiform layer (Fig. 1). Non-specific binding was lower and more uniform than total binding (Figs. 1, 2). Non-specific binding was higher in the RPE-choroid complex than in the retina. The qualitative pattern of labeling in the retina was similar with both ligands. However, the non-specific labeling of the RPE-choroid complex was markedly lower with $\left[{ }^{125} \mathrm{I}\right] \mathrm{Leu}^{8}, \mathrm{D}-\mathrm{Trp}^{22}$, $\mathrm{Tyr}^{25}$-somatostatin-28 than with $\left[{ }^{125} \mathrm{I}\right] \mathrm{Tyr}^{11}{ }^{11}$-somatostatin-14.

The wide band of labeling usually fell over the inner half of the retina (see Materials and Methods) and encompassed the region from the retinal ganglion cell layer to the outer plexiform layer (Fig. 1C, F), a distance of about $120 \mu \mathrm{m}$. We performed further measurements upon the innermost $60 \mu \mathrm{m}$ of this band. These measurements were centered kpon the inner plexiform layer.

\section{Saturation binding studies}

We measured the time-course of binding of $\left[{ }^{125} \mathrm{I}\right] \mathrm{Tyr}^{11}$-somatostatin-14 to retinal sections and found that the binding reached a plateau from 40 to $60 \mathrm{~min}$, consistent with previous findings ${ }^{22,28}$. All further measurements were made with $\mathbf{4 0} \mathrm{min}$ incubations.

Binding of $\left[{ }^{125} \mathrm{l}\right] \mathrm{Tyr}^{11}$-somatostatin-14 was measured using concentrations of $30 \mathrm{pM}-5 \mathrm{nM}$. Non-specific binding was determined in the presence of $10 \mu \mathrm{M}$ unlabeled somatostatin-14, and accounted for $30-70 \%$ of the total binding (Fig. 3). Specific binding was found to saturate at about $2.5 \mathrm{nM}$. Scatchard

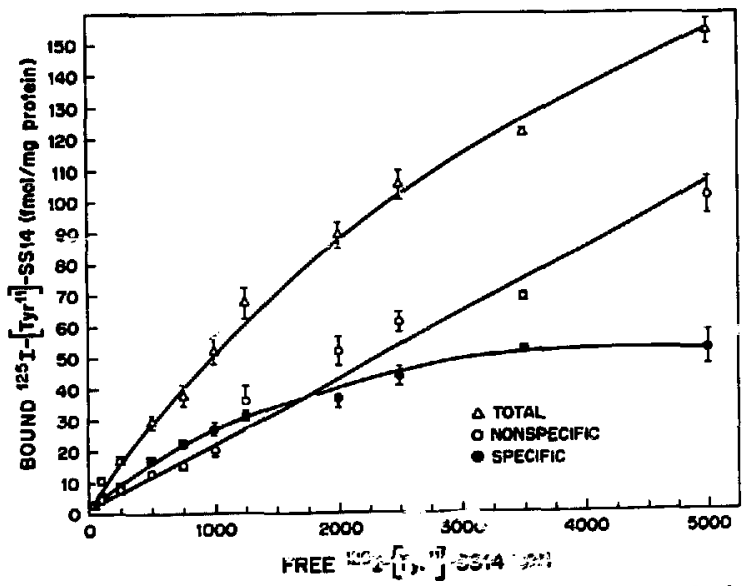

Fig. 3. Binding of $\left[{ }^{125} I\right]$ Tyr $^{11}$-somatostatin-14 tc the inner plexiform layer as a function of ligand concentration. $\triangle$. total binding; $O$, non-specific binding; and $O$, specific binding. Data are from 7 experiments (mean \pm S.E.M.). 

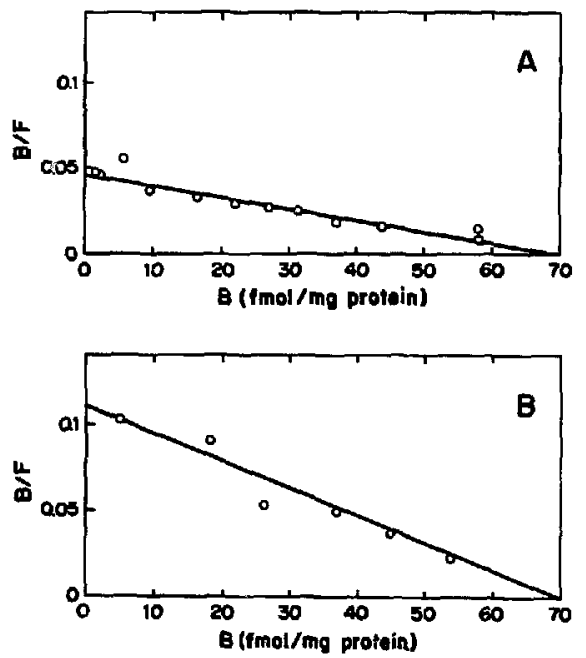

Fig. 4. Scatchard plots of specific iinding to the inner plexiform layer for $\left[{ }^{125} I \mid T y r^{11}\right.$-somatostatin-14 (A, taken from Fig. 3) and $\left.{ }^{[25} \mathrm{I}\right] \mathrm{Leu}{ }^{8}, \mathrm{D}-\mathrm{Trp}^{22}, \mathrm{Tyr}^{25}$-somatostatin-28 (B) taken from two experiments.

analysis (Fig. 4A) of the saturation data revealed a single class of binding sites with a dissociation constant $\left(K_{\mathrm{d}}\right)$ of $1.48 \mathrm{nM}$. The total number of binding sites $\left(B_{\max }\right)$ was $68 \mathrm{fmol} / \mathrm{mg}$ protein.

We studied the binding of $\left[{ }^{125} \mathrm{I}\right] \mathrm{Leu}^{8}, \mathrm{D}-\mathrm{Trp}^{22}, \mathrm{Tyr}^{25}$ somatostatin-28 using concentrations from $50 \mathrm{pM}$ to $2.5 \mathrm{nM}$. Non-specific binding was measured in the presence of $10 \mu \mathrm{M}$ unlabeled somatostatin-28, and accounted $20-50 \%$ of the total binding. Scatchard analysis (Fig. 4B) revealed the presence of a single class of binding sites with $K_{\mathrm{d}}$ of $625 \mathrm{pM}$ and $B_{\max }$ of 69 fmol/mg protein.

\section{Binding competition studies}

The ability of somatostatin-14, somatostatin-28, somatostatin-28(1-14) and bombesin to compete with the binding of $\left[{ }^{125} \mathrm{I}\right] \mathrm{Tyr}^{11}$-somatostatin-14 or $\left.{ }^{125} \mathrm{I}\right] \mathrm{Leu}^{8}, \mathrm{D}-\mathrm{Trp}^{22}, \mathrm{Tyr}^{25}$-somatostatin-28 to retinal sections was measured. In concentrations as high as 1 $\mu \mathrm{M}$, somatostatin-28(1-14) did not significantly reduce the binding of either ligand. Bombesin, in concentrations as high as $1 \mu \mathrm{M}$, did not significantly reduce the binding of $\left[{ }^{125} \mathrm{I}\right] \mathrm{T} \mathrm{yr}^{11}{ }^{11}$-somatostatin-14. We did not test bombesin with the other ligand.

Somatostatin- 28 was a more potent competitor than somatostatin-14 against both $\left[{ }^{125} \mathrm{I}\right] \mathrm{Tyr}^{1{ }^{11}}$-somatostatin-14 and $\left[{ }^{125} 1\right] \mathrm{Leu}^{8}, \mathrm{D}-\operatorname{Trp}^{22}, \mathrm{Tyr}^{25}$-somatostatin-28 (Figs. 5,6). The mediari inhibitory concen-

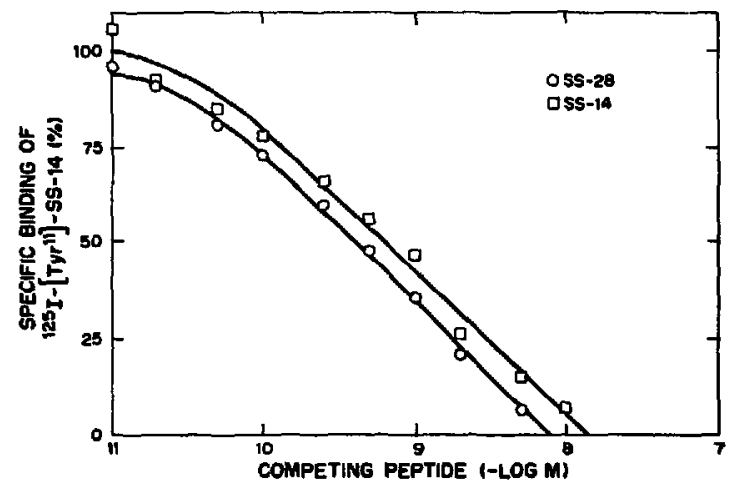

Fig. 5. Competition for the specific binding of $\left[{ }^{125} \mathrm{I}\right] \mathrm{Tyr}{ }^{11}-\mathrm{so}$ matostatin-14 by somatostatin-14 (SS-14, $\square$ ) and somatostatin28 (SS-28, O). Average data from 7 experiments (SS-14) and 4 experiments (SS-28). The inhibitory binding constant $\left(K_{\mathrm{i}}\right.$, calculated from the formula of Cheng and Prusoff ${ }^{3}$ ) was $900 \mathrm{pM}$ for somatostatin-14 and 350 pM for somatostatin-28.

tration $\left(\mathrm{IC}_{50}\right)$ against $\left[{ }^{125} \mathrm{I}\right] \mathrm{Tyr} \mathrm{T}^{11}$-somatostatin-14 was $640 \mathrm{pM}$ for somatostatin-14 and $420 \mathrm{pM}$ for somatostatin-28. Against $\left[{ }^{125} \mathrm{I}\right] \mathrm{Leu}^{8}, \mathrm{D}-\mathrm{Trp}^{22}$, $\mathrm{Tyr}^{25}$-somatostatin-28, $\mathrm{IC}_{50}$ was $3.77 \mathrm{nM}$ for somatostatin-14 and $1.2 \mathrm{nM}$ for somatostatin-28.

Statistical evaluation of the binding competition with ANOVA showed that binding of $\left.{ }^{125} \mathrm{I}\right] \mathrm{Tyr}$-somatostatin-14 was significantly less in the presence of unlabeled somatostatin- 28 than in the presence of unlabeled somatostatin-14, for all of the concentrations that were studied $\left(F_{8,1}=7.58, P<0.05\right)$. The group $\times$ treatment interaction was not statistically significant, indicating a similar dependence of [25:]Tyr ${ }^{11}$-somatostatin-14 binding upon the concentration of both competitors.

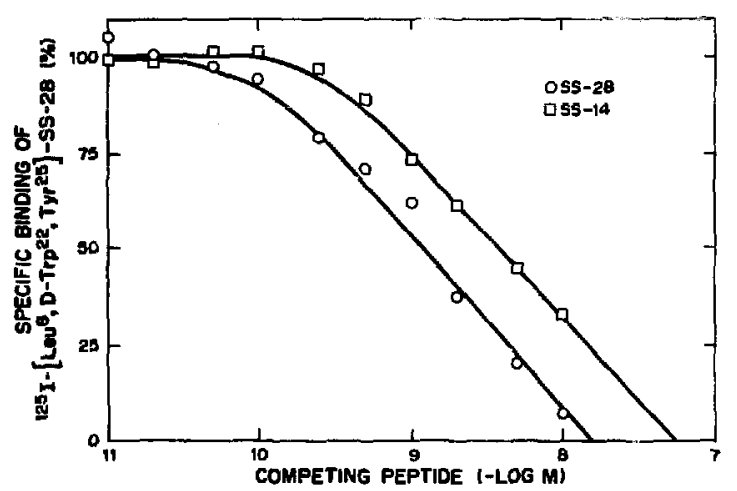

Fig. ó. Competition for the specific binding of $\left[{ }^{125} I\right] \mathrm{Leu}^{8}, \mathrm{D}-$ Trp $^{22}$, Tyr $^{25}$-somatostatin-28 by somatostatin-14 (SS-14, $\square$ ) and somatostatin-28 (SS-28, O). Average data from 2 experiments. For somatostatin-14, $K_{\mathrm{i}}$ was $4.58 \mathrm{nM}$, and for somatostatin-28 $K_{\mathrm{i}}$ was $710 \mathrm{pM}$. 
The binding of $\left[{ }^{125} \mathrm{I}\right] \mathrm{Leu}^{8}, \mathrm{D}-\operatorname{Trp}^{22}, \mathrm{Tyr}^{25}$-somatostatin-28 was also significantly less in the presence of unlabeled somatostatin- 28 than in the presence of unlabeled somatostatin-14, for all concentrations tested $\left(F_{3,1}=19.3, P<0.05\right)$. In this case the group $X$ treatment interaction was statistically significant $\left(F_{9.18}=7.74, P<0.001\right)$, indicating that the binding. of $\left[{ }^{125} \mathrm{I}\right] \mathrm{Leu}^{8}, \mathrm{D}-\mathrm{Trp}^{22}, \mathrm{Tyr}^{25}$-somatostatin-28 had a concentration dependence that was different for unlabeled somatostatin- 28 than for unlabeled somatostatin-14.

\section{DISCUSSION}

We found evidence for somatostatin receptors in the inner and outer plexiform layers of the retina, and characterized the receptors in the inner plexiform layer using labeled analogs of somatostatin-14 and somatostatin-28. A single class of binding sites are present, with a dissociation constant of $1.5 \mathrm{nM}$ for somatostatin- 14 and $0.6 \mathrm{nM}$ for somatostatin-28, and a density of about $70 \mathrm{fmol} / \mathrm{mg}$ protein. These binding sites possess the appropriate properties and occur in the appropriate location for mediating physiological effects of somatostatin, and are therefore probably somatostatin receptors.

Three measurements indicate that somatostatin-28 is somewhat more potent than somatostatin-14 in binding to retinal somatostatin receptors.

First, the dissociation constant for the binding of $\left[{ }^{125} \mathrm{I}\right] \mathrm{Tyr}^{11}$-somatostatin-14 is twice that for binding of $\left[{ }^{125} \mathrm{I}\right] \mathrm{Leu}^{8}, \mathrm{D}-\mathrm{Trp}^{22}, \mathrm{Tyr}^{25}$-somatostatin-28. Secondly, the median inhibitory concentration $\left(\mathrm{IC}_{50}\right)$ of somatostatin-14 is 3 times the $\mathrm{IC}_{50}$ of somatostatin-28 against $\left.{ }^{125} \mathrm{I}\right] \mathrm{Tyr}^{11}{ }^{11}$-somatostatin-14. Finally, the $\mathrm{IC}_{50}$ of somatostatin-14 is 4 times the $\mathrm{IC}_{50}$ of somatostatin28 against $\left.{ }^{[25} \mathrm{I}\right] \mathrm{Leu}^{8}, \mathrm{D}-\mathrm{Trp}^{22}, \mathrm{Tyr}^{25}{ }^{25}$-somatostatin-28.

Somatostatin-like immunoreactivity has been found in the retinas of many species. In the goldfish ${ }^{11}$ and the macaque ${ }^{12}$ the immunoreactive cells are presynaptic to amacrine, ganglion and bipolar cells in the inner plexiform layer. Our finding of somatostatin receptor binding in the inner plexiform layer is thus consistent with a role for the cells with somatostatin-like immunoreactivity in signal transmission. However, limitations inherent to our method do not permit cellular localization of the somatostatin re- ceptors. It is of interest to note that receptors for GABA, benzodiazepine, dopamine, adrenaline and acetylcholine are also found in the inner plexiform layer of mammalian retinas ${ }^{37}$.

A few experiments have been reported of effects of exogenous somatostatin upon the responsiveness of the retina ${ }^{24,25,30,35,36}$. However, without knowing that somatostatin receptors with the appropriate properties occur in the retina we might ascribe these effects to a non-specific action of the peptide. Our finding of a specific, high affinity receptor for somat:statin in the synapse-rich inner plexiform layer lends support to the interpretation that somatostatin has a physiological role(s) in the retina.

Retinal somatostatin receptors have a dissociation constant within the range found for the receptors in various regions of the brain $^{9.16 .17 .21 .22 .32}$. However, the density of receptors in the retina is only $40-50 \%$ of that in the brain ${ }^{16,17.21 .22}$. Perhaps the lesser density explains the less intense labeling we observed in retinal sections when compared with brain sections. Similarly, the inhibitory dissociation constants $\left(K_{\mathrm{i}}\right)$ we found for somatostatin-14 and -28 were within the range found for these compounds in brain tissue $^{9,17,28}$. We found that somatostatin-28 is more potent than somatostatin-14 in binding to retinal receptors. The same order of relative potency was found for cortical tissue by Ruebi et al. ${ }^{17}$ and Leroux et al. ${ }^{9}$ and for pituitary tissue by Srikant and Patel ${ }^{21.22}$. It is of interest to note that the more potent somatostatin28 is also more abundant than somatostatin-14 in the mouse retina (T. Yamada and L. Aldrich, in preparation).

In conclusion, we found specific, high affinity receptors for somatostatin in the inner plexiform layer of the mouse retina. This finding, taken together with immunohistochemical and physiological findings, supports the hypothesis that the neuropeptide somatostatin is either a neurotransmitter or neuromodulator in the retina.

\section{ACKNOWLEDGEMENTS}

We thank Dr.T. Chiba for helpful discussions and for reading the manuscript. Supported by NIH Grants R0 EY01221 and R01EY05205. M.K. was on leave fron the Nencki Institute, Warsaw, Poland. 


\section{REFERENCES}

1 Balkema, G.W., Mangini, N.J. and Pinto, L.H., Discrete visual defects in pearl mutant mice, Science, 219 (1983) 1085-1087.

2 Baskin, D.G., Davidson, D., Corp, E., Lewellen, T. and Graham, M., An inexpensive microcomputer digital imaging system for densitometry: quantitative autoradiography of brain insulin receptors with ${ }^{125}$ I and LKB ultrofilm, $J$. Neurosci. Methods., 16 (1986) 119-129.

3 Caro, L.G. and van Tubergen, R.P., High-resolution autoradiography, J. Cell Biol., 15 (1962) 173-188.

4 Cheng, Y.C. and Prusoff, W.H., Relationship between the inhibition constant $\left(K_{\mathrm{i}}\right)$ and the concentration of inhibitor whicl causes $50 \%$ inhibition $\left(\mathrm{IC}_{50}\right)$ of an enzymatic reaction, Bischem. Pharmacol, 22 (1973) 3033-3168.

5 Epelbaum, J., Arancibia, L.T., Kordon, C. and Enjalbert, A., Characterization, regional distribution, and subcellular distribution of ${ }^{125}$ I-Tyr-somatostatin binding sites in rat brain, J. Neurochem., 38 (1982) 1515-1523.

6 Geary, W.A., Toga, A.W. and Wooten, G.F., Quantitative film autoradiography for tritium: methodological considerations, Brain Research, 337 (1985) 99-108.

7 Kirsch, B. and Leonhardt, H., Demonstration of a somatostatir-like activity in retinal cells of the rat, Cell Tiss. Res., 204 (1979) 127-140.

8 Kuhtr, M.J. and Unnerstal, J.R., Quantitative receptor mapiping by autoradiography: some current technical problems, Trends Neurosci., (1985).

9 Leroux, P., Quirion, R. and Pelletier, G., Localization and characterization of brain somatostatin receptors as studied with somatostatin-14 and somatostatin-28 receptor radioautography, Brain Research, 347 (1985) 74-84.

10 Marshak, D.W., Reeve, J.R., Shively, J E., Hawke, D., Takami, M.S. and Yamada, T., Structure of somatostatin isolated from bovine retina, J. Neurochem., 41 (1983) 601-606.

11 Marshak, D. and Yamada, T., Characterization of somatostatin-like immunoreactivity in vertebrate retinas. Invest. Ophthalmol., 25 (1984) 112-115.

12 Marshak, D., Synapses of peptide immunoreactive neurons in macaque retina, Invest. Ophthalmol. Vis. Sci. Suppi., 27 (1986) 331.

13 Maurer, R. and Reubi, J.C., Brain somatostatin receptor subpopulation visualized by autoradiography, Brain Research, 333 (1985) 178-181.

14 Pinto, L.H., Williams, M.A., Suzuki, H., Mangini, N., Balkema, Jr., G.W. and Vanable, Jr., J.W., Visual defects in mouse hypopigmentation mutants, Neurosci. Res., Suppl. 2 (1985b) S239-S251.

15 Redburn, D.A. and Thomas, T.N., Isolation of synaptosomal fractions from rabbit retina, J. Neurosci. Methods., 1 (1979) 235-242.

16 Reubi, J.C., Evidence for two somatostatin-14 receptor types in rat brain cortex, Neurosci. Lett., 49 (1984) 259-263.

17 Reubi, J.C., Perrin, M.H., Rivier, J.E. and Vale, W., High affinity binding sites for a somatostatin- 28 analog in rat brain, Life Sci., 28 (1981) 2192-2198.

18 Rorstad, O.P., Brownstein, J.J. and Martin, J.B., Immunoreactive and biologically active somatostatin-like material in rat retina, Proc. Natl. Acad. Sci. U.S.A., 76 (1979) 3019-3023.

19 Sagar, S.M., Rorstad, O.P., Landis, D.M.D., Arnold, M.A. and Martin, J.B., Somatostatin-like immunoreactive material in the rabbit retina, Brain Research, 244 (1982) 91-99.
20 Sedmak, J.J. and Grossberg, S.E., A rapid, sensitive and versatile assay for protein using coomassie brilliant blue G250, Anal. Biochem., 79 (1977) 544-552.

21 Srikant, C.B. and Patel, Y.C.. Somatostatin receptors: identification and characterization in rat brain membranes, Proc. Natl. Acad. Sci. U.S.A., 78 (1981) 3930-3934.

22 Srikant, C.B. and Patel, Y.C., Receptor binding of somatostatin-28 is tissue specific, Nature (Lond.), 294 (1981) 259-260.

23 Spira, A.W., Shimizu, Y. and Rorstad, O.P., Localization, chromatographic characterization, and development of somatostatin-like immunoreactivity in the guinea pig retina. J. Neurosci., 4 (1984) 3069-3079.

24 Suzuki, H. and Pinto, L.H., Effects of somatostatin-14 and -28 upon the light responses of retinal ganglion cells and horizontal cells in the isolated retinas of wild-type (C57BL/6J) pearl mutant, and pearl revertant mice, Biophys. J., 49 (1986) 367a.

25 Suzuki, H. and Pinto, L.H., Response properties of horizontal cells in the isolated retina of wild-type and pearl mitant mice, J. Neurosci., 6(1986) 1122-1128.

26 Tornqvist, K., Uddmann, R., Sundler, F. and Ehinger, B , Somatostatin and VIP neurons in retina of different species, Histochemistry, 76 (1982) 137-152.

27 Tran, V.T., Beal, M.F, and Martin, J.B., Two typec of s:metostatin receptors differentiated by cyclic somatostatin analogs, Scieri:e, 228 (1985) 492-495.

28 Tran, V.T., Uhl, G.R., Perry, D.C., Manning, D.C., Vale, W.W., Perrin, M.H., Rivier, J.E., Martin, J.B. and Snyder, S.H., Autoradiographic localization of somatostatin receptors in rat brain, Eur. J. Pharmacol., 101 (1984) 307-309.

29 Unnerstall, J., Niehoff, D., Kuhar, M. and Palacios, J., Quantitative receptor autoradography using $\left[{ }^{3} \mathrm{H}\right]$ ultrofilm: application to multiple brinzodiazepine receptors, $J$. Neurcsci. Methods., 6(1982) 5s - 73.

30 Wachmeister, $L$., The action of peptides on the mudpuppy electroretinogram (ERG), Exp. Eye Res., 33 (1983) 429-437.

31 Walker, S.E. and Stell, W.K.. Gonadotropin-releasing hormone (GnRF), molluscan cardioexcitatory peptide (FMRFamide), enkephalin and related neuropeptides affect goldfish retinal ganglion cell activity, Brain Research, 384 (1986) 262-273.

32 Weightman, D.R., Whitford, C.A., Snell, C.R., Hirst, B.H., Brundish, D.E. and Kendall-Taylor, P.A., Rat brain membranes possess two high-affinity binding sites for $\left.{ }^{3} \mathrm{H}\right]$ somatostatin, Neurosci. Leti., 55 (1985) 161-166.

33 Yamada, T., Marshak, D., Basinger, S., Walsh, J., Morley, J. and Stell, W., Sonatostatin-like immunoreactivity in the retina, Proc. Natl. Acad. Sci. U.S.A., 77 (1980) 1681-1695.

34 Young, W.S., III and Kiuhar, M.J., A new method for receptor autoradiography: $\left[{ }^{3} \mathrm{H}\right]$ opioid receptors in rat brdin, Brain Research, 179 (1979) 255-270.

35 Zalutsky, R.A. and Miller, R.F., Physiological actions of neuropeptides on rabbit retinal cells, Invest. Ophthalmol., Suppl. 26 (1985) 117.

36 Zalutsky, R.A. and Miller, R.F., The physiology of somatostatin in the rabbit retina, Soc. Neurosci. Abstr., 13 (1987) 380.

37 Zarbin, M.A., Wamsley, J.K., Palacios, J.M. and Kuhar, M.J., Autoradiographic localization of high affirity GABA, benzodiazepine, dopaminergic, adrenergic and muscarinic cholinergic receptors in the rat, monkey and human retina, Brain Research, 375 (1986) 75-92. 